\title{
Проблемы и перспективы развития энергетики Бурятии ${ }^{1}$
}

\author{
Г.о. БОРИсов, кандидат экономических наук, Отдел региональных \\ экономических исследований Бурятского научного центра СО РАН, Улан-Удэ. \\ E-mail: borisovgo@bk.ru
}

Автор анализирует состояние электроэнергетики Республики Бурятия. В статье выделены главные проблемы отрасли, решение которых позволяет определить ключевые направления ее дальнейшего развития. Обоснована необходимость ввода новых энергетических объектов для повышения энергобезопасности республики, эффективности работы энергосистемы и решения экологических проблем, связанных с охраной озера Байкал, а также ввода теплофикационных мощностей Улан-Удэнской ТЭЦ-2 для повышения эффективности работы энергосистемы, решения вопросов развития города. Определено необходимое количество электроэнергии и мощности для перевода теплоснабжения Центральной экологической зоны Байкальской природной территории на электроэнергию. Показана необходимость экологически приемлемого регулирования уровня Байкала с привлечением всех мощностей электроэнергетики Байкальского региона, что должно быть учтено в разработке прогнозов развития энергосистем Байкальского региона, а также изменения «Основных правил использования водных ресурсов водохранилищ Ангарского каскада ГЭС». Предложена идея альтернативного строительству ГЭС в бассейне р.Селенги варианта электроснабжения Монголии за счет экспорта излишков электроэнергии с Гусиноозерской ГРЭС. Рассмотрены варианты электроснабжения севера Байкальского региона со строительством Мокской ГЭС.

Ключевые слова: электроэнергетика, Республика Бурятия, электропотребление, выработка электроэнергии, котельная, когенерация, Улан-Удэнская ТЭЦ-2, Мокская ГЭС, оз.Байкал

\section{Энергетическая система Республики Бурятия (РБ) включает} в себя несколько генерирующих электростанций (ЭС) общей мощностью 1403,39 МВт, на крупнейшую из которых - Гусиноозерскую ГРЭС - приходится $84,8 \%$ от суммарной мощности, и большое электросетевое хозяйство. Особенность региона высокая доля магистральных радиальных сетей и распределительных сетей низкого напряжения при большом количестве разбросанных по территории мелких потребителей.

В республике существуют два не связанных между собой энергорайона - Южный и Северобайкальский. Электроснабжение первого из них осуществляется в основном от тепловых электростанций, работающих на местном угле. Кроме того, этот район

\footnotetext{
${ }^{1}$ Статья выполнена при финансовой поддержке РФФИ, грант № 18-510-94006
} 
связан с энергосистемами Иркутской области и Забайкальского края, а также с энергосистемой центрального региона Монголии.

Северобайкальский энергорайон является транзитным между Иркутской и Забайкальской энергосистемами. Генерирующих станций здесь нет, электроснабжение осуществляется по двухцепной ЛЭП 220 кВ от «Иркутскэнерго». Основные потребители - БАМ и горнодобывающие предприятия Бодайбинского района Иркутской области. Для непревышения максимально допустимого перетока (205 МВт) в сечении Иркутск - Бурятия в период максимальных нагрузок возможен ввод ограничений режима потребления ${ }^{2}$.

В таблице 1 показана динамика выработки и потребления электроэнергии за 2013-2017 гг. и прогноз до 2022 г. С 2015 г. регион является энергоизбыточным, хотя электропотребление здесь до сих пор не достигло уровня 1990 г. (5886 млн кВт·ч).

\section{Таблица 1. Динамика потребления и выработки электроэнергии в Республике Бурятия за 2013-2017 г. и прогноз до 2022 г.}

\begin{tabular}{|l|c|c|c|c|c|c|c|c|}
\hline \multicolumn{1}{|c|}{ Показатель } & $\mathbf{2 0 1 3}$ & $\mathbf{2 0 1 4}$ & $\mathbf{2 0 1 5}$ & $\mathbf{2 0 1 6}$ & $\mathbf{2 0 1 7}$ & $\mathbf{2 0 1 8}$ & $\mathbf{2 0 2 0}$ & $\mathbf{2 0 2 2}$ \\
\hline Электропотребление, млн кВт·ч & 5484 & 5409 & 5364 & 5395 & 5479 & 5409 & 5485 & 5565 \\
\hline Выработка э/э., млн кВт·ч & 5392 & 5347 & 5476 & 5632 & 6273 & 5320 & 5920 & 6103 \\
\hline
\end{tabular}

Источник: схема и программа развития электроэнергетики Республики Бурятия на 2018-2022 гг. Утверждена распоряжением Правительства РБ от 28.04.2017 № 239-p.

Основными потребителями электроэнергии являются транспорт и связь (35\% от полезного отпуска), население (22\%) и электростанции (10\%). Энергоемкие промышленные потребители отсутствуют, крайне низка доля прежде крупных потребителей сельского и лесного хозяйства. Остаются значительными и потери в сетях (21\% от общего потребления).

Для сравнения: в промышленно развитой Иркутской области при общем потреблении электроэнергии 53209,4 млн кВт·ч доля обрабатывающих производств составляет $56,4 \%$, горнодобывающие отрасли потребляют $4,8 \%$, транспорт и связь - 7,2\%, население $-9,2 \%$, потери в сетях составляют 9,3\% ${ }^{3}$. В Забайкальском

\footnotetext{
${ }^{2}$ Схема и программа развития электроэнергетики Республики Бурятия на 2018-2022 гг. Утверждена распоряжением Правительства РБ от 28.04.2017 № 239-р.

${ }^{3}$ Схема и программа развития электроэнергетики Иркутской области на 2018-2022 гг. Утверждена Указом от 10.08.2017 г. № 140-УГ.
} 
крае структура электропотребления также выглядит гораздо лучше сбалансированной (табл. 2).

\section{Таблица 2. Структура электропотребления Республики Бурятия, Забайкальского края, Иркутской области в 2017 г.}

\begin{tabular}{|l|c|c|c|c|c|c|}
\hline \multirow{2}{*}{$\begin{array}{c}\text { Потребление } \\
\text { электроэнергии }\end{array}$} & \multicolumn{2}{|c|}{$\begin{array}{c}\text { Республика } \\
\text { Бурятия }\end{array}$} & \multicolumn{2}{c|}{$\begin{array}{c}\text { Забайкальский } \\
\text { край }\end{array}$} & \multicolumn{2}{|c|}{ Иркутская область } \\
\cline { 2 - 7 } & $\begin{array}{c}\text { млн } \\
\text { кВт·ч }\end{array}$ & $\%$ & $\begin{array}{c}\text { млн } \\
\text { кВт·ч }\end{array}$ & $\%$ & $\begin{array}{c}\text { млн } \\
\text { кВт·ч }\end{array}$ & $\%$ \\
\hline Всего & 5478,8 & 100,0 & 7812,7 & 100,0 & 54335,9 & 100,0 \\
\hline $\begin{array}{l}\text { Производство, передача и рас- } \\
\text { пределение электроэнергии, } \\
\text { газа, пара и горячей воды }\end{array}$ & 5810,0 & 10,6 & 949,1 & 12,1 & 2712,9 & 5,0 \\
\hline Потери в сетях & 1164,2 & 21,3 & 936,8 & 12,0 & 4248,6 & 7,8 \\
\hline Полезный отпуск потребителям & 3733,6 & 68,1 & 5926,8 & 75,9 & 47374,4 & 87,2 \\
\hline В том числе: & & & & & & \\
\hline Промышленность- всего & 559,8 & 10,2 & 1007,8 & 12,9 & 32806 & 60,4 \\
\hline $\begin{array}{l}\text { Сельское хозяйство, лесное } \\
\text { хозяйство, рыбоводство, охота }\end{array}$ & 20,2 & 0,4 & 9,7 & 0,1 & 639,6 & 1,2 \\
\hline Транспорт и связь & 1304,4 & 23,8 & 3094,2 & 39,6 & 3837,5 & 7,1 \\
\hline Строительство & 30,3 & 0,6 & 32,5 & 0,4 & 282,9 & 0,5 \\
\hline Прочие отрасли & 1003,8 & 18,3 & 870,1 & 11,1 & 1910,5 & 3,5 \\
\hline Население & 815,1 & 14,9 & 925,1 & 11,8 & 6424,8 & 11,8 \\
\hline
\end{tabular}

Источник: схема и программа развития электроэнергетики Республики Бурятия на 2018-2022 гг. Утверждена распоряжением Правительства РБ от 28.04.2017 г.№ 239-р. Схема и программа развития электроэнергетики Иркутской области на 2018-2022 гг. Утверждена Указом от10.08.2017 г. № 140-УГ. Схема и программа развития электроэнергетики Забайкальского края на 20182022 гг. Утверждена распоряжением от 30.04.2017 г № 180 Р.

Как видно из приведенных данных, электроэнергетика и все основные отрасли экономики республики находятся в стагнации. При этом существующие мощности электростанций позволяют не только полностью обеспечивать потребности РБ, но и передавать излишки энергии за ее пределы.

\section{Энергобезопасность и эффективность}

Несмотря на некоторую самодостаточность энергосистемы Республики Бурятия и даже небольшие излишки производимой электроэнергии, наиболее значительные ее проблемы связаны с обеспечением энергобезопасности и эффективности.

С точки зрения энергетической безопасности, как определено исследованиями ИСЭМ [Пяткова и др., 2011], Бурятия находится в предкризисном состоянии по двум факторам. Первый - это 
слишком высокая доля крупнейшего генерирующего источника (Гусиноозерской ГРЭС). Преодолеть этот недостаток без ввода новых энергомощностей не представляется возможным. Между тем в связи с незначительным ростом потребления электро- и теплоэнергии новые мощности здесь не вводились более 20 лет. Не предусмотрены они также в текущих и перспективных планах энергетических предприятий, как и в «Схеме и программе развития электроэнергетики» (СИПР) республики и РФ.

Второй фактор - высокий износ основных производственных фондов (ОПФ) энергетического хозяйства, увеличившийся с $35 \%$ в 2013 г. до 41,9\%, несмотря на реконструкцию энергоблока № 4 Гусиноозерской ГРЭС и замену турбогенератора № 7, выведенного из строя из-за пожара на Улан-Удэнской ТЭЦ-1. Действующие программы модернизации оборудования не поспевают за темпами износа. Поэтому необходимы разработка и осуществление новых эффективных программ обновления оборудования ГО ГРЭС и других электростанций, реконструкции электрических сетей, замены магистральных и внутриквартальных теплосетей, особенно в г. Улан-Удэ.

Серьезнейшей проблемой является низкая эффективность производства тепла и электроэнергии в региональной энергосистеме, которая для потребителей оборачивается повышением тарифов. В Бурятии цены на электро- и теплоэнергию - одни из самых высоких в СФО и самые высокие в Байкальском регионе. Например, во втором полугодии 2018 г. стоимость 1 кВт·ч для населения в Бурятии составляла 3,93 руб., в Забайкальском крае - 2,99 руб., в Иркутской области - 1,06 руб. Тариф на теплоэнергию, соответственно, 1616 руб., 1046 руб. и 871 руб./Гкал.

Причины низких тарифов в Иркутской области общеизвестны. Это прежде всего высокая доля (75,77\%) дешевой гидроэнергии. Но и тепловые станции этого региона вырабатывают электричество в основном на тепловом потреблении, что снижает стоимость обоих видов энергии (табл. 3).

В Забайкальском крае, где, как и в Бурятии, нет ГЭС, сложилось гораздо более сбалансированное потребление. Свыше 50\% от общего отпуска электроэнергии приходится на долю крупных потребителей (электротяга, горнодобывающие предприятия) и лишь $12 \%$ - на долю населения. 
Таблица 3. Структура выработки электроэнергии по типам электростанций

\begin{tabular}{|l|c|c|c|c|c|c|}
\hline \multirow{2}{*}{\multicolumn{1}{|c|}{ Показатель }} & \multicolumn{2}{|c|}{ Республика Бурятия } & \multicolumn{2}{|c|}{ Забайкальский край } & \multicolumn{2}{|c|}{ Иркутская область } \\
\cline { 2 - 7 } & $\begin{array}{c}\text { млн } \\
\text { кВт·ч }\end{array}$ & $\%$ & $\begin{array}{c}\text { млн } \\
\text { кВт·ч }\end{array}$ & $\%$ & $\begin{array}{c}\text { млн } \\
\text { кВт·ч }\end{array}$ & $\%$ \\
\hline $\begin{array}{l}\text { Выработка электро- } \\
\text { энергии, всего }\end{array}$ & 6273,3 & 100 & 7107,7 & 100 & 47800 & 100 \\
\hline $\begin{array}{l}\text { В том числе: } \\
\text { ГЭС }\end{array}$ & - & & - & & 35160 & 73,6 \\
\hline ТЭС & 6273,3 & 100 & 7107,7 & 100 & 12640 & 26,4 \\
\hline $\begin{array}{l}\text { В том числе: } \\
\text { ГРЭС }\end{array}$ & 5528,7 & 88 & 3514,2 & 49,4 & & \\
\hline ТЭЦ & 743 & 12 & 3593,5 & 50,6 & 12640 & 26,4 \\
\hline Прочие & 1,6 & & & & & \\
\hline
\end{tabular}

Источник: Схема и программа развития электроэнергетики Республики Бурятия на 2018-2022 гг. Утверждена распоряжением Правительства РБ от 28.04.2017 г. № 239-р. Схема и программа развития электроэнергетики Иркутской области на 2018-2022 гг. Утверждена Указом от10.08.2017 г. № 140-УГ. Схема и программа развития электроэнергетики Забайкальского края на 2018-2022 гг. Утверждена распоряжением от 30.04.2017 г. № 180 Р.

В Бурятии же всего один крупный потребитель - электротяга (35\%). Большинство остальных потребителей с незначительной нагрузкой, в том числе население (около 22\%), подключены к распределительным сетям низкого напряжения 0,4-6-10 кВт, что приводит к увеличению потерь в сетях и повышению удельных расходов на транспорт энергии. В филиале ПАО «МРСК Сибири» «Бурятэнерго» разработаны мероприятия по оптимизации сетевой инфраструктуры, но при сложившейся структуре потребления и распределения электроэнергии они не могут значительно повлиять на изменение ситуации, так же как и проводимая работа по оптимизации и повышению эффективности работы действующего оборудования на электростанциях.

Но все же основной причиной низкой эффективности и высоких тарифов на электро- и теплоэнергию в Бурятии является слишком низкая доля когенерации (комбинированного производства электроэнергии и тепла). Выработка электроэнергии на тепловом потреблении здесь составляет около $12 \%$ (в Забайкальском крае - более 50\%) от общего производства электроэнергии в регионе (табл. 3). Между тем эта технология позволяет значительно повысить коэффициент полезного действия (КПД) тепловой электростанции. Для сравнения: КПД 
ГРЭС в среднем равен 30-35\%, а ТЭЦ $-50-85 \%$ в зависимости от загрузки по теплу.

В Бурятии сбалансировать местную энергосистему по теплу и электричеству собирались еще при СССР - за счет строительства и ввода Улан-Удэнской ТЭЦ-2. В г. Улан-Удэ при тепловой нагрузке 1300 Гкал/ч лишь 380 Гкал/ч производится с использованием когенерации на ТЭЦ-1 мощностью 140 МВт. Использование когенерации при оставшейся тепловой нагрузке 920 Гкал/ч может обеспечить выработку еще не менее 700 МВт. При этом себестоимость и тепло-, и электроэнергии значительно снизится.

В 1983 г. было принято решение о строительстве 1-й очереди Улан-Удэнской ТЭЦ-2 в составе двух теплофикационных энергоблоков с общей тепловой мощностью 920 Гкал/ч. Однако затягивание строительных работ и перебои с финансированием привели к тому, что к 1995 г. были введены в эксплуатацию лишь четыре котла пускопиковой котельной, чтобы не допустить срыва теплоснабжения города. Вместе с тем удалось освоить около 10 млрд руб. капиталовложений: выполнен значительный объем по сооружению вспомогательных объектов, внешних и внутриплощадочных коммуникаций, подъездных автомобильных и железнодорожных путей. Сегодня такой объем основных фондов, с одной стороны, значительно удорожает стоимость тепла, вырабатываемого на ТЭЦ-2, с другой - позволяет снизить размер инвестиций, необходимых для ввода в эксплуатацию энергоблоков (согласно расчетам ТГК-14, для этого требуется вложить еще 33 млрд руб.).

В настоящее время централизованное теплоснабжение города осуществляется от 136 источников, в том числе: от ТЭЦ-1, ТЭЦ-2, принадлежащих ОАО «ТГК-14» (они обеспечивают $61 \%$ тепловой нагрузки города $\left.{ }^{4}\right), 34$ муниципальных и 100 ведомственных котельных. При этом стоимость выработки тепла на муниципальных и ведомственных котельных в 2-3 раза выше, чем на ТЭЦ.

Центральным отоплением обеспечено $82 \%$ площади жилых зданий. Малоэтажная застройка в пригородных микрорайонах в основном отапливается от индивидуальных теплоисточников,

\footnotetext{
${ }^{4}$ Схема теплоснабжения г. Улан-Удэ на период до 2028 г. Утв. Постановлением Администрации г. Улан-Удэ от 03.11.2017 № 322 .
} 
использующих уголь или дрова. При этом высокая стоимость тепла приводит к тому, что даже в зоне действия Улан-Удэнских ТЭЦ-1, ТЭЦ-2 продолжается ввод новых малых котельных на угле для теплоснабжения офисных, торговых и складских зданий, а также жилых кварталов. В городе продолжает ухудшаться экологическая обстановка.

Ввод мощностей ТЭЦ-2 позволит решить следующие проблемы в г. Улан-Удэ:

1) полнее обеспечить возрастающие потребности города в тепле;

2) закрыть часть среднего давления Улан-Удэнской ТЭЦ-1, мелкие и средние котельные в центре города и демонтировать морально и физически изношенное оборудование;

3) повысить надежность электроснабжения города, снизить потери в сетях;

4) значительно улучшить экологическую обстановку в городе (ТЭЦ-2 будет оснащена наиболее эффективными очистными сооружениями и находится вне зоны загрязнения);

5) повысить энергобезопасность республики за счет появления второго мощного источника генерации и обновления энергетического оборудования;

8) повысить экономическую эффективность электро- и теплоснабжения города за счет выработки электроэнергии на тепловом потреблении;

9) появится возможность стабилизации и снижения тарифов на тепло- и электроэнергию.

Однако неоднократные просьбы руководства Республики Бурятия в Минэнерго и Правительство РФ о завершении строительства ТЭЦ-2 не были удовлетворены по причине отсутствия заинтересованности собственника объекта (ТЭЦ входит в ТГК-14, которая контролируется ООО «Энергопромсбыт», дочерней компанией ПАО «РЖД»). В свою очередь Минэнерго РФ отказывает во вводе теплофикационных энергоблоков на ТЭЦ-2 ввиду профицита электроэнергии в Бурятии. Руководство республики предложило включить ТЭЦ-2 в «Программу модернизации ТЭС в РФ до 2035 г.». Но без решения проблемы сбыта электроэнергии невозможно привлечь инвестиции в строительство ТЭЦ.

На наш взгляд, этот вопрос можно и необходимо решить с учетом прогнозируемого роста потребления электроэнергии 
или создания резерва мощности в ОЭС Сибири. Так, СИПР электроэнергетики России на 2017-2023 гг. прогнозирует прирост потребления электроэнергии в Сибири с 210,091 млрд кВт·ч в 2018 г. до 226,595 млрд кВт·ч и прирост мощности соответственно с 31131 МВт до 33361 МВт. Кроме того, возможное появление в системе излишков электроэнергии с более низкой, чем сегодня, себестоимостью, позволяет по-новому взглянуть на экспортные возможности региона.

\section{«Байкальский фактор» в энергосистеме Бурятии}

Сегодня ограничения, связанные с особым природоохранным режимом Центральной экологической зоны (ЦЭЗ) оз. Байкал, серьезно затрудняют развитие эффективного и экологичного электро- и теплоснабжения территории. Между тем электроэнергетика может внести немалую лепту в решение задач, связанных с сохранением экологии озера.

1. Необходимо найти более приемлемое решение для электро- и теплоснабжения Центральной экологической зоны (ЦЭЗ) оз. Байкал.

Среди объектов энергетики наибольшее воздействие на природную среду прибрежных районов оказывают многочисленные теплоисточники: Байкальская ТЭЦ и свыше 100 мелких котельных, работающих на разном топливе - от газа и дров до угля и электричества. Общая мощность котельных равна 417,7 Гкал/ч, в том числе на территории Иркутской области производится 128,9 Гкал/ч, в Республике Бурятия - 288,8 Гкал/ч. Только от сжигания 295,1 тыс. т угля выбросы загрязняющих веществ достигают 26,7 тыс. т в год, из них 11,8 тыс. т «обеспечивают» котельные, расположенные на территории Иркутской области, 14,9 тыс. т - на территории Бурятии.

Учет вклада в загрязнение атмосферы индивидуального жилья, небольших круглогодичных туристических баз и частных предприятий, отапливаемых индивидуальными котельными, затруднен из-за отсутствия статистических данных о расходах топлива. Но можно попытаться дать экспертную оценку.

На той части Центральной экологической зоны Байкальской природной территории (ЦЭЗ БПТ), которая административно относится к Республике Бурятия, по данным за 2006 г., проживают чуть более 80 тыс. человек в 75 населенных пунктах. 
Расчеты автора показывают, что на индивидуальное отопление они расходуют в год около 125 тыс. Гкал теплоэнергии, для производства которых требуется примерно 60 тыс. т угля. Такое количество сжигаемого угля ежегодно дает около 5 тыс. т выбросов в атмосферу, около 25 тыс. т золошлаковых отходов [Борисов, 2017].

В перечне мероприятий федеральной целевой программы «Охрана озера Байкал и социально-экономическое развитие Байкальской природной территории на 2012-2020 гг.» на территориях субъектов Федерации, расположенных на Байкальской природной территории, были предусмотрены мероприятия по модернизации систем теплоснабжения с переводом на экологически чистые технологии, намечен ввод 39 объектов суммарной мощностью 325,33 Гкал/ч. Фактически же производилась замена устаревших, изношенных котлов на новые угольные, хотя и более современные, но способные обеспечить лишь незначительное снижение образования золошлаковых отходов и вредных выбросов в атмосферу (последние, кстати, по непонятным причинам не были включены в итоговые индикаторы ФЦП). Считаю, что такой вид модернизации бесперспективен.

Гораздо более экологичным способом обогрева небольших объектов являются газовые и электрокотельные. Однако в связи с невозможностью в ближайшем будущем обеспечить побережье оз. Байкал сетевым природным газом, отсутствием газораспределительной сети и высокими ценами на сжиженный природный газ, наиболее подготовленным видится обеспечение энергои теплоснабжения побережья за счет электроэнергии.

В Иркутской области благодаря низким энерготарифам электротеплоснабжение в малых поселениях развивается достаточно активно, в том числе в зоне Байкальской природной территории. Для того, чтобы полностью перевести иркутскую часть ЦЭЗ БПТ на электрообогрев, необходимо, по расчетам автора, 190 МВт электроэнергии (130 для малых котельных, 60 - для индивидуальной застройки). В Республике Бурятия для этого потребовалось бы 228 МВт (400 млн кВт·ч в год) [Борисов, 2017].

Единственным препятствием для перехода на эту технологию являются тарифы на электроэнергию, которые в Бурятской части ЦЭЗ БПТ почти в четыре раза выше, чем в Иркутской. На наш взгляд, из соображений экологической безопасности было бы 
целесообразно установление на всей территории ЦЭЗ БПТ единых тарифов на электроэнергию, конкурентных другим видам топлива (не выше 1 рубля за кВт·ч). Введение такого тарифного режима в особо охраняемой зоне вполне по силам Минэнерго РФ. Что касается технических вопросов, они вполне решаемы. Нужное количество энергии можно получить с шин Ангарских ГЭС. В частности, необходимые Бурятии 400 млн кВт·ч - это менее $1 \%$ их годовой выработки. Энергетическая инфраструктура в свою очередь в основном имеет возможность обеспечить электротеплоснабжение побережья Байкала. Остается лишь завершить строительство ЛЭП-220 кВ «Татаурово - Горячинск - Баргузин» на участке Горячинск - Баргузин и построить ЛЭП-500 кВ «Усть-Кут - Нижнеангарск». Кроме того, вследствие увеличения нагрузки и повышения категорийности потребителей, потребуется усиление распределительных сетей и подстанций.

Добавим, что для снижения экологической нагрузки на ЦЭЗ БПТ необходимо также максимально применять схемы использования тепловых насосов, энергии термальных вод, ветровой и солнечной энергии.

2. Исследование колебаний уровня оз. Байкал и предупреждение их последствий для природы и хозяйственной деятельности БПТ.

Труды ученых Байкальского института природопользования СО РАН, Иркутского лимнологического института СО РАН и др. показывают, что колебания водного уровня оз. Байкал оказывают значительное влияние на его биоту. Наиболее серьезные проблемы несут предельные уровни, возникающие в экстремально маловодные и многоводные годы.

Страдает не только экология. В 1982 г. в результате длительного маловодия 1976-1982 гг. и управленческих просчетов было допущено снижение уровня озера до 455,27 м, что привело к потере более 2 млн кВт мощности на Братской ГЭС. Такой объем тепловые электростанции не смогли возместить, даже работая на пределе своих возможностей. В результате была парализована работа почти всей промышленности Сибири. Во всех регионах Сибири были введены лимиты потребления электроэнергии, отключено уличное освещение городов, предприятия переводились на ночной режим, вводились ограничения движения по Транссибу, иногда возникала угроза отключения даже жизненно важных 
объектов: котельных, систем водоснабжения и канализации, больниц, оборонных предприятий. После тщательного расследования причин и последствий ЧП правительство СССР приняло срочные меры по открытию новых и расширению действующих угольных предприятий, а также меры по защите экологии оз. Байкал. Тогда же были установлены предельные уровни озера: 457,0 верхний, 456,0 - нижний (в тихоокеанской системе высот).

Результаты маловодья 2014-2017 гг. широко известны. Правительство РФ ограничилось лишь рассмотрением возможности снижения минимального уровня оз. Байкал ${ }^{5}$, чтобы обеспечить работу водозаборов Иркутска и Ангарска. В частности, в последнем на данный момент Постановлении № 1667 решено минимальное значение уровня воды в оз. Байкал установить на отметке 455,54 м; максимальное - на отметке 457,85 м.

При обосновании предельно допустимых значений использовались расчеты Института водных проблем РАН, однако в ходе этой работы не были рассмотрены возможности изменения режима работы ГЭС, позволяющие избежать нарушений предельных уровней озера. Так, по нашему мнению, проблема предельного снижения уровня Байкала в 2015-2016 гг. с целью обеспечения водоснабжения Иркутска и Ангарска вообще бы не возникла, если бы своевременно была снижена выработка электроэнергии на гидроэлектростанциях каскада за счет дополнительной загрузки мощностей тепловых электростанций региона. Недостаточно проработаны и требования к сезонным режимам уровня Байкала.

На наш взгляд, задачу экологически приемлемого регулирования уровня должны решать энергетики каскада ангарских ГЭС с привлечением всех мощностей электроэнергетики Байкальского региона. Это должно быть учтено в разработке прогнозов развития энергосистем Байкальского региона.

С учетом вышесказанного необходимо внести коррективы в действующие «Основные правила использования водных

\footnotetext{
${ }^{5}$ Были приняты постановления № 97 от 4 февраля 2015 г. «О предельных значениях уровня воды в озере Байкал при осуществлении хозяйственной и иной деятельности в осенне-зимний период 2014/15 года», № 626 от 1 июля 2016 г. «О максимальных и минимальных значениях уровня воды в озере Байкал в 2016-2017 годах» и № 1667 от 27 декабря 2017 г. «О максимальных и минимальных значениях уровня воды в озере Байкал в 2018-2020 годах».
} 
ресурсов водохранилищ Ангарского каскада ГЭС», которые учитывают необходимость обеспечения многих условий по стоку Ангары (судоходство, водоснабжение городов и поселков, затопление во время паводков и т.д.). Но основным критерием должно стать обеспечение уровенного режима, позволяющего сохранить биоразнообразие и уникальные береговые зоны Байкала. При этом необходимо иметь в виду, что предельные значения могут допускаться лишь в исключительных случаях длительного многолетнего катастрофического изменения водной приточности бассейна озера. Необходимо также выполнить мероприятия по обеспечению устойчивой работы водохозяйственных объектов, защите поселков от наводнений по нижнему бьефу ГЭС при экстремальных значениях водности.

3. Значительную угрозу экологии оз. Байкал представляет намечаемое строительство ГЭС на реке Селенга и ее притоках.

По прогнозам энергетического института Монгольского университета науки и технологий, электрическая нагрузка и электропотребление Центральной энергосистемы Монголии (ЦЭС) к 2025-2030 гг. увеличатся более чем в два раза и составят 2000-2200 МВт и 10 млрд кВт•ч соответственно. Основные перспективные потребители - горнообогатительные комбинаты «Оюу Толгой» и «Цагаан Суврага», угольный разрез на Таван Толгойском месторождении, а также промышленный парк в г. Сайншанд. Для обеспечения растущих потребностей в электроэнергии планируется строительство нескольких тепловых угольных электростанций и каскада ГЭС на р. Селенга и ее притоках [Борисов, 2015]. Уже разработаны ТЭО четырех ГЭС. Основные характеристики их представлены в таблице 4.

Однако «Научные исследования по оценке воздействия на трансграничный бассейн реки Селенги в границах Российской Федерации в связи с планами строительства гидроэнергетических объектов на территории Монголии», выполненные Институтом систем энергетики им. Л.А. Мелентьева СО РАН совместно с Институтом общей экспериментальной биологии CO РАН, показывают, что строительство ГЭС в Монголии нанесет значительный урон экологии бассейнов р. Селенги и оз. Байкал. О нецелесообразности и опасности строительства ГЭС на Селенге говорили эксперты и участники общественных слушаний в г. Улан-Удэ. 
Таблица 4. Характеристики планируемых ГЭС Монголии

\begin{tabular}{|c|c|c|c|c|}
\hline Показатель & ГЭС Эгийн & ГЭС Чаргайт & ГЭС Орхон & ГЭС Шурэн \\
\hline Высота порта, м & 95,7 & 60 & 90 & 65 \\
\hline Длина порта, м & 800 & 486.5 & 495 & 1200 \\
\hline Площадь водного бассейна, км² & 125 & 43 & $60 \mathrm{k}$ & 203 \\
\hline Вместимость водного бассейна & 4 млрд м ${ }^{3}$ & 1090 млн м ${ }^{3}$ & 700 млн м ${ }^{3}$ & 3.3 млрд м ${ }^{3}$ \\
\hline Установленная мощность, МВт & 315 & 24.6 & 100 & 245 \\
\hline $\begin{array}{l}\text { Производство электроэнергии } \\
\text { в год }\end{array}$ & 500 млн кВт.ч & 116.6 млн кВт.ч & 219 млн кВт·ч & 900 ГВТ.ч \\
\hline Сумма инвестиций, млн долл. & 870,0 & 95,66 & 160 & 730,0 \\
\hline IRR, \% & 13 & 7,7 & 10 & 14,7 \\
\hline Срок окупаемости, лет & $15-20$ & $15-20$ & $13-16$ & $10-13$ \\
\hline Уровень исследований & ТЭО выполнено & ТЭО выполнено & ТЭО выполнено & $\begin{array}{c}\text { ТЭО выполня- } \\
\text { ется }\end{array}$ \\
\hline
\end{tabular}

Источник: По данным доклада доктора Г. Ендонгомбо «Проект ГЭС Шурэн».

Считаем, что энергетикам России и Монголии необходимо рассмотреть альтернативные варианты электроснабжения Монголии, в том числе, например, строительство ЛЭП-500кВ из г. Гусиноозерск в Монголию, на уровне глав правительств согласовать экспортные цены на электроэнергию [Борисов, 2016].

\section{Электроснабжение северных районов Бурятии и Байкальского макрорегиона}

Север Байкальского региона, прилегающий к Байкало-Амурской магистрали, является единственной в России территорией, где вводятся ограничения потребления электроэнергии из-за отставания строительства ЛЭП-500кВ «Усть-Кут - Нижнеангарск». Одной из причин задержек является необходимость соблюдать требования Ф3 «Об охране озера Байкал» (запрет на рубку просек, на размещение электроподстанций большой мощности в ЦЭЗ БПТ и т.д.). Вместе с тем прилегающие к БАМу районы Иркутской области, Республики Бурятия и Забайкальского края имеют большой экономический потенциал. На этой территории обнаружены богатейшие залежи полезных ископаемых: золота, никеля, меди, железа, угля, асбеста, калия, глинозёма, кварца, кремния и др. По большинству месторождений утверждены запасы, проданы лицензии на разработку, определены собственники и операторы разработок. Близость к железнодорожной магистрали значительно снижает транспортные издержки. В настоящее время по ряду проектов выполнен комплекс подготовительных работ, включая 
оценку запасов в соответствии с российскими и международными требованиями, проведение опытно-промышленных испытаний и подготовку технико-экономических обоснований. Крупнейшими проектами на севере Забайкальского края являются создание горно-обогатительных комбинатов на базе Удоканского месторождения меди и Чинейского железорудного месторождения. В Муйском районе Республики Бурятия находятся в эксплуатации Ирокиндинское и Кедровское золоторудные месторождения, имеется ряд перспективных месторождений золота, титаномагнетитовых руд, олова, бериллия, платины, асбеста, цементного сырья. На севере Иркутской области расположено несколько больших золоторудных месторождений, включая крупнейшее в России «Сухой Лог». Однако развитие горнорудной промышленности в регионе сдерживают нерешённые вопросы энергоснабжения. По предварительной оценке, общая мощность перспективных потребителей этой зоны превышает 1000 МВт.

Стратегия развития Дальнего Востока и Байкальского региона предусматривает строительство на границе Республики Бурятия и Забайкальского края Мокской ГЭС с Ивановским контррегулятором мощностью 1410 МВ (табл. 4) для обеспечения электроэнергией новых потребителей в районах перспективной добычи и переработки полезных ископаемых [Дондоков и др., 2015].

Таблица 5. Показатели Мокского гидроэнергетического комплекса

\begin{tabular}{|l|c|c|c|}
\hline \multicolumn{1}{|c|}{ Показатель } & Мокская ГЭС & Ивановский контррегулятор & Всего \\
\hline Мощность, МВт & 1200 & 210 & 1410 \\
\hline $\begin{array}{l}\text { Выработка электроэнергии, } \\
\text { млрд кВт.ч }\end{array}$ & 4,54 & 1,03 & 5,57 \\
\hline $\begin{array}{l}\text { Стоимостьстроительствавценах } \\
\text { III кв. 2012 г., млрд руб. }\end{array}$ & 108,9 & 15,6 & 124,5 \\
\hline
\end{tabular}

Источник: Технико-экономическое обоснование Мокского гидроузла. СанктПетербург: АО «Ленгидропроект», 1997, 338 с.

При проектировании Мокской ГЭС учитывалось ее нахождение в центре перспективных нагрузок потребителей, удаленных от ближайших источников генерации (Усть-Илимской ГЭС и Нерюнгринской ГРЭС) более чем на 1000 км. Мокская ГЭС является частью проектируемого Витимского гидроэнергетического комплекса, который должен взять на себя роль «энергетического моста» между объединенной энергосистемой Дальнего Востока и ЕЭС России, обеспечить энергобезопасность севера 
Байкальского региона, снизить тарифы на электроэнергию на его территории, повысить возможность России стать серьезным поставщиком электроэнергии на азиатский рынок. Актуальность строительства Мокской ГЭС для Бурятии обусловлена тем, что бассейн р. Витим является единственной территорией республики без воздействия «байкальского фактора». Требуется комплексное рассмотрение Схемы энергоснабжения этого региона и юга Якутии, где основными источниками электроэнергии могут стать Мокская ГЭС и Витимский каскад электростанций.

Основные направления развития ТЭК России и ее регионов определены в «Энергетической стратегии России на период до 2035 г.» [Волков, 2010], в 2018 г. завершается работа над «Стратегией социально-экономического развития России до 2035 г.», «Стратегией социально-экономического развития Республики Бурятия до 2035 г.». На наш взгляд, назрела необходимость разработки новой Стратегии развития энергетики Бурятии с учетом проблем, рассмотренных в данной статье, вытекающих из задач комплексного развития макрорегиона в условиях экологических ограничений.

\section{Литература}

Борисов Г.О. Потенциал и проблемы развития энергосистем Забайкальского региона и Монголии // Вестник БГУ: Экономика и право. 2015. № 2. С. 116-123.

Борисов Г.О. Варианты теплоэнергоснабжения центральной экологической зоны байкальской природной территории // Вестник Бурятского научного центра Сибирского отделения Российской академии наук. 2017. № 2 (26). С. 103-109.

Борисов Г.О., Дондоков З.Б.-Д. Проблемы трансграничного и межрегионального взаимодействия по использованию гидроэнергетического потенциала бассейна озера Байкал // Записки Забайкальского отделения Русского географического общества. Вып. 135: Географические исследования приграничнопериферийных районов в рыночных условиях. Чита: ЗабГУ, 2016. С. 146-151

Волков Э.П., ОАО «Энергетический институт им. Г.М. Кржижановского» (ЭНИН). О концепции модернизации электроэнергетики // Электрические станции, 2010. № 9. С. 5-16.

Дондоков З.Б.-Д., Борисов Г.О. Хозяйственное освоение зоны БАМ: проблемы и перспективы комплексного освоения севера Байкальского региона // Региональная экономика. 2015. № 48. С. 15-25.

Пяткова Н.И. и др. Энергетическая безопасность России: проблемы и пути решения/ Отв. ред. Н.И. Воропай, М.Б. Чельцов. Новосибирск: Изд-во СО PAH, 2011. 198 c. 


\section{Summary}

\section{Borisov G. O., Buryatia Scientific Center, SB RAS, Ulan-Ude}

\section{Problems and Prospects of Energy Development in Buryatia}

The author analyzes the condition of the power industry of the Republic of Buryatia. The article highlights the main problems of the industry, the solution of which allows us to determine the main directions for further development of the industry. The necessity of commissioning new energy facilities for increasing the energy security of the republic, the efficiency of the energy system and solving ecological problems related to the protection of Lake Baikal is grounded. The necessity of development and implementation of new effective programs for updating equipment of power plants, reconstruction of electric and heat networks is shown. The necessity of the introduction of the heating capacities of Ulan-Ude CHPP-2 for increasing the efficiency of the energy system, solving the issues of city development is substantiated.

The tasks of power engineers arising in connection with the protection of Lake Baikal are considered.

The required amount of electricity and capacity for transferring heat supply to the Central Ecological Zone of the Baikal Nature Territory for electricity

The necessity of ecologically acceptable regulation of the Baikal level with attraction of all capacities of the electric power industry of the Baikal region is shown, which should be taken into account in the development of forecasts of the development of the energy systems of the Baikal region, as well as changes in the "Basic rules for the use of water resources in the reservoirs of the Angara cascade of HPPs".

It is proposed to consider alternative power supply options for Mongolia instead of building hydropower plants in the Selenga river basin, including the construction of a 500 $\mathrm{kV}$ transmission line from Gusinoozersk to Mongolia.

The variants of power supply in the north of the Baikal region with the construction of the Mokskaya HPP are considered.

Power sector; Republic of Buryatia; energy consumption; power generation; thermal power plants; cogeneration; Ulan-Ude CHP-2; Mokskaya HPP; the Lake Baikal

\section{References}

Borisov G. O. (2015) Potential and problems of development of power systems of the Transbaikal region and Mongolia. Bulletin of BSU: Economics and Law. No. 2. Pp. 116-123. (In Russ.)

Borisov G.O. (2017) Variants of heat supply of the central ecological zone of the Baikal natural territory. Bulletin of the Buryat Scientific Center of the Siberian Branch of the Russian Academy of Sciences. No. 2 (26). Pp. 103-109. (In Russ.)

Borisov G. O., Dondokov Z.B.-D. (2016) Problems of Transboundary and Interregional Cooperation on the Use of the Hydropower Potential of the Lake Baikal. Notes of the Transbaikal Branch of the Russian Geographical Society. Issue. 135: Geographical studies of border-peripheral areas under market conditions. Chita: ZabUU. Pp. 146-15. (In Russ.)

Volkov E.P. (2010) Academician of the Russian Academy of Sciences, JSC "Krzhizhanovsky Power Engineering Institute" (ENIN). About the concept of modernization of the electric power industry. Electric stations. No. 9. Pp. 5-16. (In Russ.)

Dondokov Z.B.-D., Borisov G. O. (2015) Economic development of the BAM zone: problems and prospects for the integrated development of the northern Baikal region. [Regional economy]. No. 48. Pp. 15-25. (In Russ.)

Pyatkova N.I. (2011) Energy security of Russia: problems and solutions. Executive Editor N.I. Voropai, M. B. Cheltsov. Novosibirsk: SB RAS Publishing House. 198 p. (In Russ.) 